\title{
Effects of insemination timing and GnRH treatment on pregnancy rates of N'Dama cattle after estrus induction with progestin
}

\author{
Marcel Okouyi M'foumou W'otari ${ }^{1,2}$ Christian Hanzen ${ }^{1 *}$
}

\begin{abstract}
Keywords
Bos taurus, induced ovulation, progestogen, artificial insemination, fertility, Gabon
\end{abstract}

\footnotetext{
Submitted: 21 April 2016

Accepted: 12 October 2016

Published: 26 October 2016
}

\begin{abstract}
Summary
The aim of this clinical trial was to quantify the results of pregnancy after treating trypanotolerant N'Dama female cattle $(n=168)$ with a progesterone-releasing intravaginal device (CIDR; $1.38 \mathrm{~g}$ of progesterone) inserted for seven days. An intramuscular (IM) prostaglandin injection (500 $\mathrm{\mu g}$ of cloprostenol) was administered two days before removal of the device. Subsequently, an IM injection of $400 \mathrm{IU}$ of eCG was administered when the device was removed. The animals were inseminated 48 (Group 1) and 72 hours (Group 2) after removal of CIDR. In both groups, half the animals were treated with $4.2 \mu \mathrm{g}$ of buserelin acetate and the other half with $1 \mathrm{ml}$ of physiological saline. Four protocols were thus tested: CIDR-PG-eCG/IA48h, CIDR-PG-eCG/IA48h/GnRH+, CIDRPG-eCG/IA72h, and CIDR-PG-eCG/IA72h/GnRH+. A pregnancy diagnosis was performed by echography 45 to 60 days after insemination. The average pregnancy rate was $37.5 \%$. That of the adult cows $(43.2 \%, \mathrm{n}=111)$ was significantly $(\mathrm{p}<0.03)$ higher than that of the heifers $(26.3 \%, \mathrm{n}=57)$. The pregnancy rate observed in animals in Group $2(48.8 \%)$ was significantly higher $(p<0.002)$ than that observed in animals in Group 1 (26.2\%). The physiological condition and injection of $\mathrm{GnRH}$ at the time of insemination had no significant impact on the pregnancy rate. The hormonal protocol using CIDR-PG-eCG (400 IU) and a timed artificial insemination 72 hours later improved the pregnancy rates in N'Dama females.
\end{abstract}

- How to cite this article: Okouyi M.W.M., Hanzen C., 2016. Effects of insemination timing and GnRH treatment on pregnancy rates of N'Dama cattle after estrus induction with progestin. Rev. Elev. Med. Vet. Pays Trop., 69 (2): 73-78

\section{INTRODUCTION}

Given its hardy nature, its butchery quality and its trypanotolerance, the N'Dama breed represents a significant potential for developing African cattle breeding (Akouango et al., 2010). It therefore constitutes an important source of protein for the African population. His genetic improvement involves the use of artificial insemination. However, factors such as nutrition, management and estrus detection efficiency affect the use of this biotechnology in most African cattle operations.

\footnotetext{
1. University of Liège, Faculty of Veterinary Medicine, boulevard de Colonster, 20-Bat. B42-4000, Sart-Tilman, Liège, Belgium.

2. Masuku University of Science and Technology, Gabon.

* Corresponding author

Email: christian.hanzen@ulg.ac.be
}

The most useful alternative to use artificial insemination is to apply a hormonal protocol that allows artificial insemination without the need of estrus detection, a protocol usually referred to as fixed-time artificial insemination (FTAI). According to the legal availability of the hormones, two types of FTAI protocols currently used in cattle are gonadotropin-releasing hormone $(\mathrm{GnRH})$ or estradiol-based protocols, in both cases combined with progestin devices (Progesterone-Releasing Intravaginal Device or PRID; Controlled Internal Drug-Releasing Device or CIDR) (Bo and Baruselli 2014). In cycling animals, GnRH-based protocols have been recommended in dairy (Pursley et al., 1995) and beef cattle (Geary et al., 2001; Baruselli et al., 2004; Bo and Baruselli, 2014). In brief, the first injection of $\mathrm{GnRH}$ induces LH release and ovulation of the dominant follicle (if any) with the emergence of a new follicular wave one to two days later. Prostaglandin F2alpha is given six to seven days later to induce luteal regression and a second $\mathrm{GnRH}$ is given 56 hours after prostaglandin-F (PGF) (Ovsynch protocol) or at the same time as FTAI (Cosynch protocol). To increase the probability of an ovulation at 
the second injection of GnRH or to use such protocol in non-cycling animals, a progestin-releasing device can be given between the first injection of GnRH and PGF. Such progestin addition improves the pregnancy rate in heifers (Martinez et al., 2002a; Martinez et al., 2002b) and beef cows (Lamb et al., 2001). Attending the high prevalence of postpartum anestrus cows in beef herds, authors recommend to use the protocol based on progestin administered during 7,8 or 9 days (Bo et al., 2007; Martinez et al., 2002a).

The application of equine chorionic gonadotropin (eCG) at the time of removal of a progestin has been recommended in Bos taurus with a high prevalence of postpartum anestrus (Bo et al., 2007). eCG stimulates the growth of the dominant follicle, its ovulation (Sa Filho et al., 2010a) and the synthesis of progesterone by the subsequent corpus luteum (Sa Filho et al., 2010b). Moreover, the application of eCG at the time of removal of a progestin influences the follicle size at ovulation and increases the pregnancy rate (Sa Filho et al., 2010c).

At our best knowledge, very few studies have been devoted to the effects of hormonal protocols on pregnancy rates in the N'Dama breed. They are generally accompanied by a great variability in observed estrus and pregnancy rates (Okouyi et al., 2014). An injection of $\mathrm{GnRH}$ at insemination seems to improve the pregnancy rates (Voh et al., 2004; Kamga-waladjo et al., 2006). In a previous study we also showed that the injection of high levels of eCG at the time of CIDR removal increased the intensity and the frequency of estrus signs, the follicular growth rate and the ovulation rate, but also the percentage of animals who present multiple ovulations (Okouyi et al., 2015; Okouyi and Hanzen 2016). Our study aimed to compare the pregnancy rates of a hormonal protocol combining progestin, PGF and $\mathrm{eCG}$ with $\mathrm{GnRH}$ given at two different times of insemination.

\section{MATERIALS AND METHODS}

The experiment was conducted on Nyanga Ranch in Gabon $\left(0^{\circ} 23^{\prime}\right.$ 24" N; 9 24' 7" E) between June and September 2014, a period corresponding to the main dry season, which is marked in terms of nutrition by a qualitative and quantitative reduction in grazing resources. Heifers $(n=57)$ and suckler cows $(n=111)$ from the N'Dama breed were maintained on natural pastures and given free access to water. All the cows had calved four to six months ago. All animals had been vaccinated against contagious bovine pleuropneumonia (Peri T1/SR vaccine, Laboratoire national vétérinaire, Bamako, Mali), treated against parasites (diminazen, Veriben 2,36 g; isometamidium, Verigium $125 \mathrm{mg}$; Ceva Santé animale, Libourne, France) and weighed. Their body condition score (BCS) was identified by measuring fatty deposits at the base of the tail using a scale from 1 to 5: $1=$ thin and 5= fat (Ayres et al., 2009).

The cycling (presence of corpus luteum) or non-cycling (absence of corpus luteum) status was determined by performing at a two-week interval an ultrasound ovarian examination (KX 5200V scan, 6,5 MHz linear probe, Xuzhou Kaixin Electronic Instrument, Hamburg, Germany).

All the animals $(\mathrm{n}=168 ; 5.4 \pm 1.0$ years; $236.1 \pm 23.7 \mathrm{~kg}$; $\mathrm{BCS}=2.7$ \pm 0.4 ) were treated for seven days with a progestin administered vaginally (CIDR $1.38 \mathrm{~g}$ of progesterone, Zoetis Louvain-la-Neuve, Belgium) (Figure 1). An intramuscular (IM) injection of $\mathrm{PGF}_{2 \alpha}(2 \mathrm{ml}$ of Estrumate $250 \mu \mathrm{g} / \mathrm{ml}$ of cloprostenol; Intervet, Brussels, Belgium) was administered 48 hours before removal of CIDR $\left(\mathrm{D}_{0}\right)$. An IM injection of $400 \mathrm{IU}$ of eCG (2 ml of Folligon $1000 \mathrm{IU} / 5 \mathrm{ml}$; Intervet Belgium) was administered on the day of CIDR removal. A vaginoscopy was conducted on the day CIDR was removed to identify the degree of the animals' tolerance. The mucus was examined and noted on a scale of 1 to 5 ( $1=$ absence of mucus; $5=$ abundant brown to red mucus). A value lower than 3 indicated a good tolerance of CIDR (Chenault et al., 2003).
The animals were split into two groups, G1 and G2 ( $=84$ in each group), and were inseminated 48 and 72 hours, respectively, after CIDR removal using a single dose of semen from the Senepol breed (Alta Genetics Do Brazil, Uberaba-MG, Brazil). During insemination, half the animals (GnRH+) were given an IM injection of $4.2 \mu \mathrm{g}$ of buserelin acetate ( $2.5 \mathrm{ml}$ of Receptal; Intervet, Brussels, Belgium). Each group was subdivided into two batches ( $\mathrm{GnRH}+$ and $\mathrm{GnRH}-)$. The other half was not treated and constituted the control group (GnRH-), receiving $1 \mathrm{ml}$ of saline solution (sodium chloride $0.9 \%$; FRESENIUS KABI, Sevres, France). Pregnancy was confirmed by ultrasonography between 45 and 60 days after insemination.

Statistical analysis was carried out using SAS software (version 9.1). The differences of our treatment protocols were tested on the fertility of female N'Dama. The effectiveness of each treatment was assessed based on significant differences between pregnancy rates (\%). Conditional and non-conditional logistical regression models were used to assess the interaction between pregnancy rates and risk factors (factors likely to vary them); age, weight, body condition, cyclicity (cycled vs non-cycled), parity (heifer vs cow), time of insemination (48 hours vs 72 hours), and the addition of GnRH (GnRH+ vs GnRH-). A first, non-conditional logistical regression model was used to assess the interactions between the pregnancy rate and each risk factor considered in isolation. Based on this analysis, only risk factors with a value of $p<0.025$ were considered in the conditional logistical regression. The most appropriate model was chosen using the stepwise procedure.

\section{RESULTS}

No significant statistical difference between age, weight, body condition or reproductive parameters (\% of cycling animals) was observed between the four experimental groups (Table I). Retention and tolerance rates (no abnormal vaginal discharge at CIDR withdrawal) were 100 and $98 \%$, respectively. The pregnancy rates obtained after insemination are presented in Table II.

The average pregnancy rate of female N'Dama $(n=168)$ was $37.5 \%$. That of cows $(43.2 \%)$ was significantly higher $(p<0.03)$ than that of heifers (26.3\%). Inseminations carried out 72 hours (Group 2) after removal of CIDR led to pregnancy rates $(48.8 \%)$ which were significantly higher $(\mathrm{p}<0.002)$ than those observed after inseminations carried out 48 hours (Group 1) after withdrawal (26.2\%). Similar differences were observed among cows (54.5 vs $32.1 \%$; $p<0.01)$ and among heifers ( 37.9 vs $14.3 \%$; $<<0.03$ ).

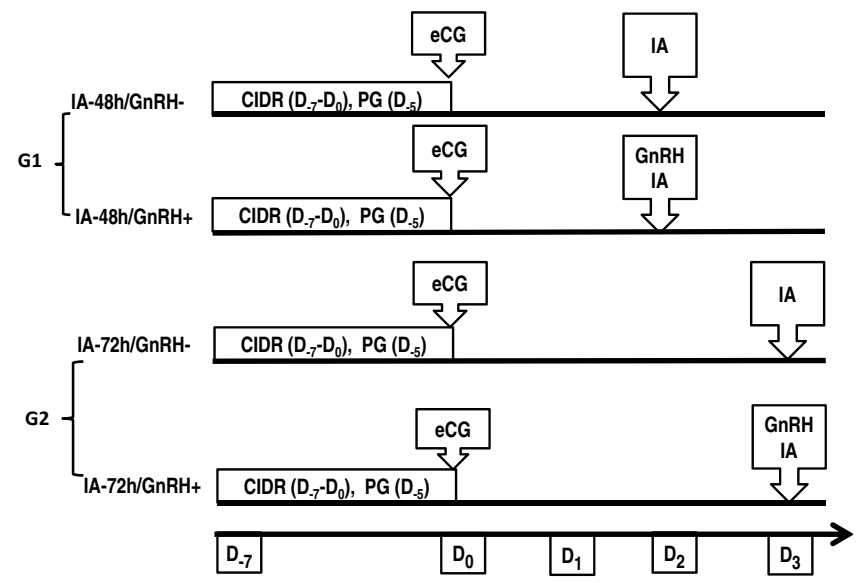

Figure 1: Hormonal protocol for synchronising oestrus and insemination of female N'Dama in a ranch in Gabon. 
Table I

Distribution and characteristics of female N'Dama in a ranch in Gabon

\begin{tabular}{|c|c|c|c|c|c|c|}
\hline & \multicolumn{2}{|c|}{ Group 1} & \multicolumn{2}{|c|}{ Group 2} & \multirow[b]{2}{*}{ RMSE } & \multirow[b]{2}{*}{$\mathbf{P}$} \\
\hline & GnRH- & GnRH+ & GnRH- & GnRH+ & & \\
\hline \multicolumn{7}{|l|}{ Cows + heifers $(n=168)$} \\
\hline Number (batch) & 42 & 42 & 42 & 42 & NA & - \\
\hline Age (years) & 5.5 & 5.6 & 5.4 & 5.0 & 0.98 & 0.07 \\
\hline Weight (kg) & 233.4 & 239.2 & 237.3 & 234.4 & 23.8 & 0.66 \\
\hline Body condition score* & 2.6 & 2.7 & 2.8 & 2.7 & 0.35 & 0.34 \\
\hline Females cycled (\%) & 71.4 & 73.8 & 66.7 & 71.4 & NA & 0.62 \\
\hline \multicolumn{7}{|l|}{ Cows $(n=111)$} \\
\hline Number (batch) & 28 & 28 & 27 & 28 & NA & - \\
\hline Age (years) & 6.1 & 6.2 & 6.1 & 5.5 & 0.4 & 0.77 \\
\hline Weight (kg) & 241.5 & 242.1 & 244.4 & 242.0 & 22.5 & 0.12 \\
\hline Body condition score & 2.6 & 2.6 & 2.7 & 2.6 & 0.3 & 0.31 \\
\hline Cows cycled (\%) & 71.4 & 71.4 & 66.7 & 69.9 & NA & 0.14 \\
\hline \multicolumn{7}{|l|}{ Heifers $(n=57)$} \\
\hline Number & 14 & 14 & 15 & 14 & NA & - \\
\hline Age (years) & 4.2 & 4.3 & 4.0 & 4.2 & 0.4 & 0.11 \\
\hline Weight (kg) & 217.1 & 233.2 & 224.5 & 219.3 & 20.3 & 0.07 \\
\hline Body condition score & 2.8 & 3.0 & 3.0 & 2.9 & 0.3 & 0.71 \\
\hline Heifers cycled (\%) & 71.4 & 78.6 & 66.7 & 78.6 & NA & 0.09 \\
\hline
\end{tabular}

GnRH: gonadotropin releasing hormone; RMSE = root mean square error; NA = not applicable; * On a scale of 1 to $5,1=$ thin and $5=$ fat

\section{Table II}

Pregnancy rates of N'Dama heifers and cows in a ranch in Gabon according to the time of insemination and injection of $\mathrm{GnRH}(n=168)$

\begin{tabular}{|c|c|c|c|c|c|}
\hline & \multicolumn{2}{|c|}{ Group 1 (48 hours) (\%) } & \multicolumn{2}{|c|}{ Group 2 (72 hours) (\%) } & \multirow[t]{2}{*}{$\mathbf{P}$} \\
\hline & $\mathrm{GnRH}-$ & $\mathrm{GnRH}+$ & $\mathrm{GnRH}-$ & $\mathrm{GnRH}+$ & \\
\hline Num. of cows + heifers & 42 & 42 & 42 & 42 & \\
\hline Pregnancy by batch $(\%)$ & $21.4^{\mathrm{a}}$ & $31.0^{\mathrm{a}}$ & $52.4^{\mathrm{b}}$ & $45.2^{b}$ & 0.01 \\
\hline Pregnancy by group (\%) & \multicolumn{2}{|c|}{$26.2^{\mathrm{c}}(\mathrm{n}=84)$} & \multicolumn{2}{|c|}{$48.8^{d}(n=84)$} & 0.002 \\
\hline Average pregnancy (\%) & \multicolumn{4}{|c|}{$37.5(n=168)$} & \\
\hline Num. of cows & 28 & 28 & 27 & 28 & \\
\hline Pregnancy by batch (\%) & 25.0 & 39.3 & 59.3 & 50 & 0.06 \\
\hline Pregnancy by group (\%) & \multicolumn{2}{|c|}{$32.1^{\mathrm{e}}(\mathrm{n}=56)$} & \multicolumn{2}{|c|}{$54.5^{f}(n=55)$} & 0.01 \\
\hline Average pregnancy (\%) & \multicolumn{4}{|c|}{$43.2(n=111)$} & \\
\hline Num. of heifers & 14 & 14 & 15 & 14 & \\
\hline Pregnancy by batch (\%) & 14.3 & 14.3 & 40.0 & 35.7 & 0.24 \\
\hline Pregnancy by group (\%) & \multicolumn{2}{|c|}{$14.3^{g}(n=28)$} & \multicolumn{2}{|c|}{$37.9^{h}(n=29)$} & 0.03 \\
\hline Average pregnancy (\%) & \multicolumn{4}{|c|}{$26.3(n=57)$} & \\
\hline
\end{tabular}

GnRH: gonadotropin releasing hormone

Numbers followed by different letters on a same line indicate a significant difference $(\mathrm{p}<0.05)$.

The physiological status of female cattle had no significant effect on the pregnancy percentages $[38.7 \%$ in cycling animals $(n=119)$ vs $34.7 \%$ in non-cycling animals $(n=49)]$. This lack of significant differences was observed in cows (44.2 vs $41.2 \%$ ) and heifers (28.6 vs
20.0\%). No significant effect of the physiological status (cycling vs non-cycling) was observed within the groups of animals inseminated after 48 hours (Group 1) (26.2 vs 26.1\%) or after 72 hours (Group 2) (51.7 vs $42.3 \%)$. 
For all cows and heifers, the injection of $\mathrm{GnRH}$ at insemination did not significantly increase pregnancy rates in animals inseminated 48 hours (31.0 vs $21.4 \%$; $\mathrm{p}>0.05$ ) or 72 hours (45.2 vs $52.4 \%$; $\mathrm{p}>0.05$ ) after removal of CIDR. Furthermore, no significant difference was observed within Groups 1 and 2 both in cows (Group 1: 39.3 vs 25.0\%; Group 2: 50.0 vs 59.3\%) and in heifers (Group 1: 14.3 vs 14.3\%; Group 2: 35.7 vs $40.0 \%$ ).

\section{DISCUSSION}

The average pregnancy rate was $37.5 \%$ (63/168). It was significantly $(\mathrm{p}<0.05)$ higher in cows $(43.2 \%$; $48 / 111)$ than in heifers $(26.3 \%$; $15 / 57)$. These results agree with the pregnancy rate observed after synchronization of beef heifers and cows in temperate countries, i.e. between 21 (Favetto et al., 2010) and 60.8\% (Grimard et al., 2001), and between 26 (Lucy et al., 2001) and 68.4\% (Mialot et al., 1998), respectively.

A study performed in 1387 herds and involving 266,978 artificial inseminations has reported an average pregnancy rate of $49.5 \%$ (10 to $82 \%$ ) (Bo and Baruselli 2014). Different factors can influence the pregnancy rates in beef cattle. The average body weight (236.1 $\pm 23.7 \mathrm{~kg})$ and body condition score $(2.7 \pm 0.4)$ of the animals in the present study carried out during the long dry season were comparable to the minimum value required to enable female N'Dama to reproduce (Ezanno et al., 2005). The body condition score is one of the most important factors affecting the pregnancy rate of beef females (Bo and Baruselli, 2014). Animals treated with progestins must have a BCS higher than 2.5 and ideally higher than 3 to achieve pregnancy rates of 50\% or higher (Bo et al., 2007).

We did not observe any significant differences in pregnancy rates between heifers (28.6 vs $20.0 \%$ ) and cows (44.2 vs $41.2 \%$ ), regardless of their cyclicity. This observation disagrees with that of Lucy et al. (2001) who reported a better pregnancy rate in cycling (49\%; 57/116) than in non-cycling $(28 \% ; 29 / 105)$. The same difference has been reported for cows with 46\% (64/140) vs 26\% (36/141) (Lucy et al., 2001). Contrary to Lucy et al. (2001) we have used systematic insemination and not insemination on observed estrus. Moreover we have systematically injected eCG at time of CIDR removal. So, an injection of eCG appears indispensable to improve the ovulatory response (Baruselli et al., 2004) and pregnancy rates (Dias et al., 2009).

The pregnancy rates of heifers (14.3 vs $37.9 \%$ ) and cows (31.2 vs $54.5 \%$ ) inseminated 48 hours after withdrawal of CIDR appear to be significantly lower than that of animals inseminated after 72 hours. In beef cattle, various insemination protocols were assessed: upon observed heat, systematic single insemination at 56 hours, and double insemination at 48 and 72 hours after removal of the progestogen (Roche et al., 1978; Anderson et al., 1982). The choice of time to inject the prostaglandin or eCG as well as the time of insemination must also take into account the conditions in which the animals were restrained, the quality of detection and the work required, because these conditions may constitute an additional stress factor for the animals (Grimard et al., 2003). Our protocol involved handling the animals four times. It would be interesting to assess the effects of simultaneously injecting eCG and prostaglandin (Lamb, 2013), a method which would reduce the number of times the animals need to be handled to three.

In Nelore suckling cows treated with norgestomet, the interval between implant removal and ovulation was $72.0 \pm 3.1$ hours in the control animals (eCG-/GnRH-; $\mathrm{n}=12), 70.5 \pm 2.7$ hours in the eCG animals $(\mathrm{eCG}+/ \mathrm{GnRH}-; \mathrm{n}=13), 69.6 \pm 2.4$ hours in the $\mathrm{GnRH}$ animals $(\mathrm{eCG}-/ \mathrm{GnRH}+; \mathrm{n}=12)$ and $73.1 \pm 1.1$ hours in the eCG/GnRH $(\mathrm{eCG}+/ \mathrm{GnRH}+; \mathrm{n}=13)$ animals. No significant differences were observed between these various batches (Sà Filho et al., 2010a). The gap between the end of the progestogen-based treatment and ovulation was on average $81.8 \pm 3.75$ hours in beef heifers treated using the CIDR/PG protocol (Leitman et al., 2008). In female N'Dama $(\mathrm{n}=120)$ treated using a CIDR, 25.0, 57.4 and $17.6 \%$ of ovulations appeared respectively 48-72 hours, 73-96 hours and 97-120 hours after removal. The average value was $80.4 \pm 12.4$ hours (Okouyi et al., 2015). Given the fertilization capacity of spermatozoa (24 hours), the fecundity of the oocyte (16 to 18 hours) and the duration of migration of the spermatozoa in the genital tract (6 to 8 hours), it is recommended to conduct insemination 0 to 16 hours prior to ovulation (Saumande and Humblot, 2005; Roelofs et al., 2006). Without a doubt, in case of a single insemination, a 72-hour timescale is preferable to that of 48 hours.

Injecting $\mathrm{GnRH}$ at the same time as insemination has the effect of increasing pituitary secretion of the follicle-stimulating hormone (FSH) and luteinizing hormone (LH), and thus of encouraging final growth of the follicle and ovulation (Martinez et al., 2014). In the present case, this injection did not significantly increase the pregnancy rate in cycling and non-cycling heifers and cows. Our observations are similar to those obtained in suckling Bos indicus cattle from the Nelore breed which were either treated with GnRH or untreated after heat was induced using norgestomet, combined (or not) with injections of eCG or GnRH (Sà Filho et al., 2010a).

\section{- CONCLUSION}

In female cycling or non-cycling N'Dama with optimal weight and body condition, the use of the hormonal protocol CIDR-PG-eCG (400 IU), followed by a timed artificial insemination 72 hours following the removal of CIDR, increased the pregnancy rates in N'Dama females. Such protocol alleviates the constraints of estrus detection. It would be interesting to verify the effects of injecting PG when removing CIDR or at the weaning time.

\section{Acknowledgments}

The authors thank the Programme d'appui institutionnel et Développement des ressources humaines (PAI-DRH) in Gabon for funding this study, the Société d'investissement pour l'agriculture tropicale (SIAT-Gabon) for the workspace, and the Clinical Department for Animal Production at the Faculty of Veterinary Medicine at the University of Liège (ULg, Belgium).

\section{REFERENCES}

Akouango F., Ngokaka C., Ewomango P., Kimbembe E., 2010. Morphometric and reproductive characterization of N'Dama cows and bulls in Congo [in French]. Anim. Genet. Resour., 46: 41-47, doi: $10.1017 /$ S2078633610000688

Anderson G.W., Babonis G.D., Riesen J.W., Woody C.O., 1982. Control of estrus and pregnancy in dairy heifers treated with synchro-mate-B. Theriogenology, 17: 623-633

Ayres H., Ferreira R.M., Torres-Júnior J.R.S., Demétrio C.G.B., De Lima C.G., Baruselli P.S., 2009. Validation of body condition score as a predictor of subcutaneous fat in Nelore (Bos indicus) cows. Livest. Sci., 123: $175-179$

Baruselli P.S., Reis E.L., Marques M.O., Nasser L.F., Bó G.A., 2004. The use of hormonal treatments to improve reproductive performance of anestrous beef cattle in tropical climates. Anim. Reprod. Sci., 82-83: 479-486, doi: 10.1016/j.anireprosci.2004.04.025

Bó G.A., Baruselli P.S., 2014. Synchronization of ovulation and fixedtime artificial insemination in beef cattle. Animal, 8 (s1): 144-150, doi: $10.1017 /$ S1751731114000822

Bo G.A., Cutaia L., Peres L.C., Pincinato D., Baruselli Marana P.S., 2007. Technologies for fixed-time artificial insemination and their influence on reproductive performance of Bos indicus cattle. Soc. Reprod. Fertil., 64: $223-236$ 
Chenault J.R., Boucher J.F., Dame K.J., Meyer J.A., Wood-Follis S.L., 2003. Intravaginal progesterone insert to synchronize return to oestrus of previously inseminated dairy cows. J. Dairy Sci., 86 (6): 2039-2049, doi: 10.3168/jds.S0022-0302 (03) 73793-X

Dias C.C., Wechsler F.S., Day M.L., Vasconcelos J.L., 2009. Progesterone concentrations, exogenous equine chorionic gonadotropin, and timing of prostaglandin $\mathrm{F}(2 \mathrm{alpha})$ treatment affect fertility in postpuberal Nelore heifers. Theriogenology, 72 (3): 378-385, doi: 10.1016/j. theriogenology.2009.03.006

Ezanno P., Ickowicz A., Lancelot R., 2005. Relationships between N'Dama cow body condition score and production performance under an extensive range management system in Southern Senegal: Calf weight gain, milk production, probability of pregnancy, and juvenile mortality. Livest. Prod. Sci., 92 (3): 291-306, doi: 10.1016/j. livprodsci.2004.09.001

Favetto P.H., Hoar B.R., Myers D.M., Tindall J., 2010. Progesterone inserts may help to improve breeding readiness in beef heifers. Calif. Agric., 64 (2): 106-111

Geary T.W., Salverson R.R., Whittier J.C., 2001. Synchronization of ovulation using GnRH or hCG with the CO-Synch protocol in suckled beef cows. J. Anim. Sci., 79 (10): 2536-2541

Grimard B., Benoit-Valiergue H., Ponter A.A., Maurice T., Humblot P., 2001. Synchronisation of beef cows: results of three years of use in farms [in French]. Elev. Insémin., 302: 3-15

Grimard B., Humblot P., Ponter A.A., Chastant S., Constant F., Mialot J.P., 2003. Effectiveness of oestrus synchronization treatment in cattle [in French]. Prod. Anim., 16: 211-227

Kamga-Waladjo A.R., Mbaïndingatoloum F.M., Lapo R.A., Thiam O., Sultan J., Diop P.E.H., 2006. N'Dama reproduction characteristics used in bovine artificial insemination in Republic of Guinea [in French]. Rev. Afr. Santé Prod. Anim., 4 (1-2): 69-72

Lamb G.C., 2013. Control of estrus in cows. In: Proc. Applied Reproductive Strategies in Beef Cattle, Staunton, VA, USA, 15-16 Oct. 2013, 81-96

Lamb G.C., Stevenson J.S., Kesler D.J., Garverick H.A., Brown D.R. Salfen B.E., 2001. Inclusion of an intravaginal progesterone insert plus $\mathrm{GnRH}$ and prostaglandin F2alpha for ovulation control in postpartum suckled beef cows. J. Anim. Sci., 79 (9): 2253-2259

Leitman N.R., Busch D.C., Bader J.F., Mallory D.A., Wilson D.J., Lucy M.C., Ellersieck M.R., Smith M.F., Patterson D.J., 2008. Comparison of protocols to synchronize estrus and ovulation in estrous-cycling and prepubertal beef heifers. J. Anim. Sci., 86 (8): 1808-1818, doi: 10.2527/jas.2008-0970

Lucy M.C., Billings H.J., Butler W.R., Ehnis L.R., Fields M.J., Kesler D.J., Kinder J.E., Mattos R.C., Short R.E., Thatcher W.W., Wettemann R.P., Yelich J.V., Hafs H.D., 2001. Efficacy of an intravaginal progesterone insert and an injection of PGF2alpha for synchronizing estrus and shortening the interval to pregnancy in postpartum beef cows, peripubertal beef heifers, and dairy heifers. J. Anim. Sci., 79 (4): 982995

Martínez M.F., Kastelic J.P., Adams G.P., Cook B., Olson W.O., Mapletoft R.J., 2002a. The use of progestins in regimens for fixed-time artificial insemination in beef cattle. Theriogenology, 57 (3): 1049-1059

Martinez M.F., Kastelic J.P., Adams G.P., Mapletoft R.J., 2002b. The use of a progesterone-releasing device (CIDR-B) or melengestrol acetate with $\mathrm{GnRH}, \mathrm{LH}$, or estradiol benzoate for fixed-time $\mathrm{Al}$ in beef heifers. J. Anim. Sci., 80 (7): 1746-1751
Martinez M.F., Tutt D., Quirke L.D., Tattersfield G., Juengel J.L., 2014. Development of a GnRH-PGF2 $\alpha$-progesterone-based synchronization protocol with eCG for inducing single and double ovulations in bee cattle. J. Anim. Sci., 92 (11): 4935-4948, doi: 10.2527/jas.2013-7512

Mialot J.P., Noel F., Puyalto C., Laumonier G., Sauveroche B., 1998. Treatment of postpartum anoestrus in dairy cows with CIDR-E or prostaglandin F2 $\alpha$ [in French]. Bull. Group. Tech. Vet., 2: 29-38

Okouyi M.W.M., Drion P.V., Hanzen C.,2015. Preovulatory follicle diameter, growth rate and time of ovulation during induced oestrus using a CIDR in trypanotolerant female Bos taurus N'Dama cattle. Trop. Anim. Health Prod., 47 (8): 1443-1448, doi: 10.1007/s11250015-0881-9

Okouyi M.W.M., Hanzen C., 2016. Effects of equine chorionic gonadotropin (eCG) on the sexual behaviour and ovulatory characteristics of female African N'Dama cattle. Rev. Med. Vet., 167 (7-8): 211-215

Okouyi M.W.M., Kamga-Waladjo A.R., Diara S., Hanzen C., 2014. Reproduction characteristics of the trypanotolerant female N'Dama [in French]. Rev. Afr. Santé Prod. Anim., 12 (1): 3-7

Pursley J.R., Mee M.O., Wiltbank M.C., 1995. Synchronization of ovulation in dairy cows using PGF2 $\alpha$ and GnRH. Theriogenology, 44 (7): 915-923

Roche J.F., Prendiville D.J., Gosling J., 1978. Synchronization of oestrus and pregnancy diagnosis in heifers bred in autumn and winter. Vet. Rec., 102: 12-14

Roelofs J.B., Graat E.A., Mullaart E., Soede N.., Voskamp-Harkema W., Kemp B., 2006. Effects of insemination-ovulation interval on fertilization rates and embryo characteristics in dairy cattle. Theriogenology, 66 (9): 2173-2181, doi: 10.1016/j. theriogenology.2006.07.005

Sà Filho M.F., Ayres H., Ferreira R.M., Marques M.O., Reis E.L., Silva R.C., Rodrigues C.A., Madureira E.H., Bo G.A., Baruselli P.S., 2010a Equine chorionic gonadotropin and gonadotropin-releasing hormone enhance fertility in a norgestomet-based, timed artificial insemination protocol in suckled Nelore (Bos indicus) cows. Theriogenology, 73 (5): 651-658, doi: 10.1016/j.theriogenology.2009.11.004

Sá Filho M.F., Crespilho A.M., Santos J.E.P., Perry G.A., Baruselli P.S. 2010b. Ovarian follicle diameter at timed insemination and estrous response influence likelihood of ovulation and pregnancy after estrous synchronization with progesterone or progestin-based protocols in suckled Bos indicus cows. Anim. Reprod. Sci., 120 (1-4): 23-30, doi: 10.1016/j.anireprosci.2010.03.007

Sà Filho M.F., Torres-Junior J.R., Penteado L., Gimenes L.U., Ferreira R.M., Ayres H., Castro E., Paula L.A., Sales J.N., Baruselli P.S., 2010c. Equine chorionic gonadotropin improves the efficacy of a progestin-based fixed-time artificial insemination protocol in Nelore (Bos indicus) heifers. Anim. Reprod. Sci., 118 (2-4): 182-187, doi: 10.1016/j.anireprosci.2009.10.004

Saumande J., Humblot P., 2005. The variability in the interval between estrus and ovulation in cattle and its determinants. Anim. Reprod. Sci., 85 (3-4): 171-182, doi: 10.1016/j.anireprosci.2003.09.009

Voh Jr A.A., Larbi A., Olorunju S.A.S., Agyemang K., Abiola B.D. Williams T.O., 2004. Fertility of N'dama and Bunaji cattle to artificial insemination following oestrus synchronization with PRID and PGF2alpha in the hot humid zone of Nigeria. Trop. Anim. Health Prod., 36 (5): 499-511, doi: 10.1023/B:TROP.0000035007.19522.62 


\section{Résumé}

Okouyi M.W.M., Hanzen C. Effets de la synchronisation de I'insémination et du traitement $\mathrm{GnRH}$ sur le taux de gestation des bovins N'Dama après induction de l'œstrus avec de la progestérone

Le but de cet essai clinique a été de quantifier les pourcentages de gestation de bovins N'Dama $(\mathrm{n}=168)$ trypanotolérants après traitement avec un dispositif intravaginal libérant de la progestérone (CIDR ; 1,38 g de progestérone) inséré pendant sept jours. Une injection intramusculaire (IM) de prostaglandine (500 $\mu$ g de cloprostenol) a été administrée deux jours avant le retrait du dispositif. Par la suite, une injection IM de 400 UI de gonadotrophine chorionique équine (eCG) a été administrée lorsque le dispositif a été retiré. Les animaux ont été inséminés 48 (groupe 1) et 72 heures (groupe 2) après le retrait du CIDR. Dans les deux groupes, la moitié des animaux ont été traités avec 4,2 $\mu \mathrm{g}$ d'acétate de buséréline et l'autre moitié avec $1 \mathrm{ml}$ de sérum physiologique. Quatre protocoles ont ainsi été testés : CIDR-PG-eCG/IA48h, CIDR-PG-eCG/ IA48h/GnRH+, CIDR-PG-eCG/IA72h et CIDR-PG-eCG/IA72h/ $\mathrm{GnRH}+$. Un diagnostic de gestation a été réalisé par échographie 45 à 60 jours après l'insémination. Le pourcentage de gestation moyen a été de $37,5 \%$. Celui des vaches adultes $(43,2 \%, n=111)$ a été significativement $(p<0,03)$ plus élevé que celui des génisses $(26,3 \%, n=57)$. Le pourcentage de gestation a été significativement plus élevé $(p<0,002)$ chez les animaux du groupe $2(48,8 \%$ ) que chez ceux du groupe 1 $(26,2 \%)$. L'état physiologique et I'injection de $\mathrm{GnRH}$ au moment de l'insémination n'ont pas eu d'impact significatif sur le pourcentage de gestation. Le protocole hormonal utilisant CIDR-PG-eCG (400 UI) et une insémination systématique 72 heures après ont amélioré les pourcentages de gestation chez la femme N'Dama.

Mots-clés : Bos taurus, ovulation induite, progestagène, insémination artificielle, fertilité, Gabon

\section{Resumen}

Okouyi M.W.M., Hanzen C. Efectos del momento de inseminación y tratamiento con GnRH sobre las tasas de preñez de las hembras N’Dama después de la inducción de estro con progestina

El objetivo de este estudio clínico fue el de cuantificar los resultados de preñez después de tratar ganado hembra N'Dama trypanotolerante $(\mathrm{n}=168)$ con un dispositivo intravaginal de liberación de progesterona (CIDR; 1,38 g de progesterona) implantado durante siete días. Se administró una inyección intramuscular (IM) de prostaglandina (500 $\mu \mathrm{g}$ de cloprostenol) dos días antes de remover el dispositivo. Subsecuentemente, se administró una inyección IM de 400 UI de eCG cuando se removió el dispositivo. Los animales fueron inseminados 48 (grupo 1) y 72 horas (grupo 2) después de remover el CIDR. En ambos grupos, la mitad de los animales fueron tratados con 4,2 $\mu \mathrm{g}$ de acetato de buserelina y la otra mitad con $1 \mathrm{ml}$ de salina fisiológica. Se probaron luego cuatro protocolos: CIDR-PG-eCG/IA48h, CIDR-PG-eCG/ IA48h/GnRH+, CIDR-PG-eCG/IA72h y CIDR-PG-eCG/IA72h/ $\mathrm{GnRH}+$. Se realizó un diagnóstico de preñez mediante ecografía 45 y 60 días post inseminación. La tasa promedio de preñez fue de $37,5 \%$. Aquella de las vacas adultas $(43,2 \%$, $\mathrm{n}=111)$ fue significativamente $(\mathrm{p}<0,03)$ más alta que la de las novillas $(26,3 \%, n=57)$. La tasa de preñez observada en animales en el grupo $2(48,8 \%)$ fue significativamente más elevada $(p<0,002)$ que la observada en animales en el grupo $1(26,2 \%)$. La condición fisiológica y la inyección de GnRH en el momento de la inseminación no tuvieron un impacto significativo en la tasa de preñez. El protocolo hormonal usando CIDR-PG-eCG (400 UI) y una inseminación artificial cronológicamente controlada 72 horas después mejoró las tasas de preñez en las hembras N’Dama.

Palabras clave: Bos taurus, ovulación inducida, progestageno, inseminación artificial, fertilidad, Gabón 